\title{
(6) OPEN ACCESS \\ How are we measuring physical activity and sedentary behaviour in the four home nations of the UK? A narrative review of current surveillance measures and future directions
}

\author{
Tessa Strain, ${ }^{01}$ Karen Milton, ${ }^{2}$ Philippa Dall, ${ }^{3}$ Martyn Standage, ${ }^{4}$ Nanette Mutrie
}

\begin{abstract}
- Additional material is published online only. To view please visit the journal online (http://dx.doi.org/10.1136/ bjsports-2018-100355).

${ }^{1}$ MRC Epidemiology Unit, University of Cambridge, Cambridge, UK

${ }^{2}$ Norwich Medical School, University of East Anglia, Norwich, UK

${ }^{3}$ School of Health and Life Sciences, Glasgow Caledonian University, Glasgow, UK ${ }^{4}$ Centre for Motivation and Health Behaviour Change, Department for Health, University of Bath, Bath, UK ${ }^{5}$ Physical Activity for Health Research Centre, Moray House School of Education, University of Edinburgh, Edinburgh, UK
\end{abstract}

\section{Correspondence to} Dr Tessa Strain, University of Cambridge, MRC Epidemiology Unit, Cambridge CB2 1TN, UK; tessa.strain@mrc-epid.cam. ac.uk

Accepted 26 April 2019
Check for updates

(C) Author(s) (or their employer(s)) 2019. Re-use permitted under CC BY. Published by BMJ.

To cite: Strain T,

Milton K, Dall P, et al.

Br J Sports Med Epub ahead of print: [please include Day Month Year]. doi:10.1136/ bjsports-2018-100355

\begin{abstract}
Background/objectives To explore and describe the comparability between the surveys of the UK home nations (England, Northern Ireland, Scotland, Wales) that monitor compliance with the Chief Medical Officers' physical activity (PA) recommendations. We also suggest ways to improve the UK national PA and sedentary behaviour (SB) surveillance systems.

Methods We identified national surveys that monitor PA and SB through searching UK-wide and devolved administration websites, the Global Observatory for Physical Activity Country Cards and the Active Healthy Kids Report Cards. Subsequently, we extracted information from survey documentation on the survey commissioners and contractors, method of administration, current questionnaire details relevant to the PA recommendations, questionnaire changes over the previous decade and the most recent prevalence figures.
\end{abstract}

Results For adults and older adults, five surveys assess the moderate-to-vigorous PA (MVPA) recommendation, three assess muscle strengthening and three assess SB. For older adults only, three assess balance and co-ordination. For children, seven assess MVPA, none assess muscle strengthening and five assess SB. Only one survey reports on the under $5 \mathrm{PA}$ recommendation. There is no part of the recommendations for which comparable estimates can be calculated across all four home nations. The greatest variation is among the SB questions and reporting. No survey has regularly used device-based measures.

Conclusion UK surveillance of the PA recommendations is complex, undertaken separately in the home nations, using multiple surveys that cover adults and children separately. We recommend that the costs and benefits of harmonising the existing questionnaires are considered, along with the potential introduction of device-based measures.

\section{INTRODUCTION}

Physical activity (PA) reduces the risk of premature death from the leading non-communicable diseases including heart disease, stroke, diabetes and certain types of cancer. ${ }^{12}$ Leading a physically active lifestyle has many psychological and cognitive benefits including a reduced risk of dementia, lowered risk of depression and improved well-being. ${ }^{1} \mathrm{~A}$ dose-response relationship exists between PA and health-higher levels of activity are associated with greater health benefits, although the relationship is non-linear. ${ }^{12}$
National PA recommendations provide consensus on the amount, intensity, frequency and type of PA needed to improve health and reduce the risk of non-communicable diseases. ${ }^{3}$ These recommendations are typically based on comprehensive systematic reviews of the best available scientific evidence linking PA to a range of health outcomes $\left(\mathrm{eg},{ }^{12}\right)$.

In 2011, the Chief Medical Officers (CMOs) commissioned a review of the PA recommendations in England, Wales, Scotland and Northern Ireland (the four 'home nations'), which led to the first common set of PA recommendations across the UK. ${ }^{4}$ These recommendations emphasised the importance of PA across the life course, with separate guidance for early years (under $5 \mathrm{~s}$ ), children and adolescents, adults and older adults. In light of increasing evidence that high levels of sitting may have deleterious health effects, ${ }^{5}$ these guidelines also included a statement on sedentary behaviour (SB). The benefits of PA that strengthens muscles and improves balance beyond health ageing were also acknowledged, and were given greater prominence compared with previous home nations' policy documents. ${ }^{4}$ Summarised in box 1 are the 2011 PA recommendations for each age group.

In 2018, the CMOs appointed a number of Expert Working Groups to update these recommendations. For the first time, an Expert Working Group on Communication and Surveillance, including the authors, was commissioned to review the implications for surveillance. ${ }^{6}$ Conducting national surveillance on PA is important for benchmarking current activity levels among populations, setting targets and monitoring progress over time. ${ }^{37}$ National surveillance enables participation of the home nations in global initiatives such as the Global Observatory for Physical Activity (Go-PA!) Country Cards and large cross-national academic studies. ${ }^{8}{ }^{9}$ To date, no analysis has explored the similarities and differences between the home nations' surveys and how appropriate each survey is for assessing PA prevalence against the UK recommendations. Such an analysis is critical ahead of the publication of the 2019 recommendations ${ }^{10}$ to inform potential changes to the surveillance of PA and SB in the UK and ensure consistency across the home nations. Specifically, our aim was to review the PA and SB-related questions in the four UK home nations' surveillance systems to:

- Determine if and how they address each component of the UK recommendations; 
Box 1 The 2011 physical activity recommendations for the $\mathrm{UK}^{4}$

Early years (under $5 \mathrm{~s}$ )

- PA should be encouraged from birth, particularly through floor-based play and water-based activities in safe environments.

- Children of preschool age who are capable of walking unaided should be physically active daily for at least $180 \mathrm{~min}$ (3 hours), spread throughout the day.

- All under 5 s should minimise the amount of time spent being sedentary (being restrained or sitting) for extended periods (except time spent sleeping).

Children and young people (5-18 years)

- All children and young people should engage in moderate to vigorous intensity PA for at least $60 \mathrm{~min}$ and up to several hours every day.

- Vigorous intensity activities, including those that strengthen muscle and bone, should be incorporated at least 3 days a week.

- All children and young people should minimise the amount of time spent being sedentary (sitting) for extended periods.

\section{Adults (19-64 years)}

- Adults should aim to be active daily. Over a week, activity should add up to at least $150 \mathrm{~min}$ ( $2 \frac{1}{2} / 2$ hours) of moderate intensity activity in bouts of $10 \mathrm{~min}$ or more. Alternatively, comparable benefits can be achieved through $75 \mathrm{~min}$ of vigorous intensity activity spread across the week or a combination of moderate and vigorous intensity activity.

- Adults should also undertake PA to improve muscle strength on at least 2 days a week.

- All adults should minimise the amount of time spent being sedentary (sitting) for extended periods.

\section{Older adults (65+ years)}

- Older adults who participate in any amount of PA gain some health benefits, including maintenance of good physical and cognitive function. Some PA is better than none, and more PA provides greater health benefits.

- Older adults should aim to be active daily. Over a week, activity should add up to at least $150 \mathrm{~min}$ (21/2 hours) of moderate intensity activity in bouts of $10 \mathrm{~min}$ or more-one way to approach this is to do 30 min on at least 5 days a week. For those who are already regularly active at moderate intensity, comparable benefits can be achieved through 75 min of vigorous intensity activity spread across the week or a combination of moderate and vigorous activity.

- Older adults should also undertake PA to improve muscle strength on at least 2 days a week.

- Older adults at risk of falls should incorporate PA to improve balance and co-ordination on at least 2 days a week.

- All older adults should minimise the amount of time spent being sedentary (sitting) for extended periods.

- examine the nature of surveillance systems in terms of using questionnaires or device-based measures;

- Examine the comparability of estimates obtained from each surveillance system;

- Suggest improvements to strengthen national PA and SB surveillance systems.

\section{METHODS}

In January 2018, the CMOs appointed the authors to the Expert Working Group on Communication and Surveillance as part of the update of the UK PA recommendations. The remit was to describe the current PA and SB surveillance methods to inform decision-making and ensure the systems used are appropriate and can be aligned with the new recommendations. National surveys of PA and SB prevalence were identified (January-March 2018, updated October 2018) by searching UK-wide and devolved administration websites, the home nations' Go-PA! Country Cards ${ }^{9}$ and their Active Healthy Kids Report Cards. ${ }^{11-14}$ Inclusion criteria were that the survey (1) reports on prevalence of one or more, but not necessarily all, of the 2011 UK PA recommendations; (2) is nationally representative at a home nation or UK-wide level; and (3) has plans to re-collect data using comparable methods. Cohort studies were excluded as they track the same individuals over time and are thus inappropriate for population health surveillance. Recent results, data documentation and technical reports were obtained for surveys that met the inclusion criteria. These were located on the survey websites, UK Government/devolved administration websites and the UK Data Archive (specific references provided in the Results section).

The following information was extracted and summarised in tables for each recommendation: survey commissioners and contractors; method of administration; details of the current questionnaire relevant to the $\mathrm{PA}$ and $\mathrm{SB}$ recommendations; changes in the questionnaire over the previous decade; the most recent figures that describe the percentages of the population meeting the current recommendations. Questions relating to SB were categorised according to the TAxonomy of Self-reported Sedentary behaviours Tools (TASST) framework. ${ }^{15}$ A narrative review was undertaken to explore differences between the survey methods.

\section{RESULTS}

\section{Overview of surveys}

Table 1 presents the details of the UK surveys that have been used to monitor trends in the percentages of the population meeting one or more of the PA or SB recommendations. The Government/devolved administration departments usually commission the surveys, which are contracted out to social research companies. Most are interviewer-led computer-assisted personal interviews: Health Survey for England (HSE), ${ }^{16}$ Health Survey for Northern Ireland (HSNI), ${ }^{17}$ Scottish Health Survey (SHeS), ${ }^{18}$ Continuous Household Survey (CHS $)^{19}$ and the National Survey for Wales (NSW). ${ }^{20}$ Others are administered by telephone (the Active Lives Survey (ALS) ${ }^{21}$ and the ALS Children and Young People Surve ${ }^{22}$ ) or various methods of self-administration (Young Persons' Behaviour and Attitudes Survey (YPBAS) ${ }^{23}$ and the Health Behaviour in School-Aged Children (HBSC) $)^{24-26}$ survey).

\section{Measurement of the moderate-to-vigorous physical activity} recommendations

Adults and older adults

Table 2 presents an overview of the UK surveys' current questionnaires that assess the percentage of adults and older adults that meet the ' 150 min' moderate-to-vigorous PA (MVPA) component of the $2011 \mathrm{PA}$ recommendations, and the latest estimates.

The HSNI and the HSE use identical questionnaires. ${ }^{16} 17$ The SHeS differs from them only on occupational activity and the number of sports prompted. ${ }^{18}$ In England, the ALS is structured differently in terms of how activities are reported and does not 
Table 1 Surveys that report on the percentage of the population meeting the UK physical activity guidelines in 2018 by country and the recommendations monitored

\begin{tabular}{|c|c|c|c|c|c|c|c|c|c|c|c|}
\hline \multirow[t]{3}{*}{ Country } & \multirow[t]{3}{*}{ Survey } & \multirow[t]{3}{*}{ Commissioners } & \multirow{3}{*}{$\begin{array}{l}\text { Contracted } \\
\text { to }\end{array}$} & \multirow[t]{3}{*}{ Survey method } & \multicolumn{7}{|c|}{ Recommendation measured } \\
\hline & & & & & \multicolumn{2}{|l|}{ MVPA } & \multicolumn{2}{|c|}{ Muscle strength } & \multirow{2}{*}{$\begin{array}{l}\text { Balance } \\
\text { Older } \\
\text { adults }\end{array}$} & \multicolumn{2}{|c|}{ Sedentary behaviour } \\
\hline & & & & & $\begin{array}{l}\text { Adults/ } \\
\text { older } \\
\text { adults }\end{array}$ & Children & $\begin{array}{l}\text { Adults/ } \\
\text { older } \\
\text { adults }\end{array}$ & Children & & $\begin{array}{l}\text { Adults/ } \\
\text { older } \\
\text { adults }\end{array}$ & Children \\
\hline \multirow[t]{3}{*}{ England } & $\begin{array}{l}\text { Active Lives } \\
\text { Survey }^{21}\end{array}$ & $\begin{array}{l}\text { Sport England } \\
\text { in partnership } \\
\text { with other bodies } \\
\text { and government } \\
\text { departments }\end{array}$ & Ipsos MORI & $\begin{array}{l}\text { Postal invite to online } \\
\text { (mobile/desktop) } \\
\text { completion. Paper } \\
\text { questionnaire sent if } \\
\text { non-response }\end{array}$ & $\checkmark^{*}$ & & & & & & \\
\hline & $\begin{array}{l}\text { Health Survey for } \\
\text { England }^{16}\end{array}$ & $\begin{array}{l}\text { Department of } \\
\text { Health }\end{array}$ & $\begin{array}{l}\text { National } \\
\text { Centre } \\
\text { for Social } \\
\text { Research }\end{array}$ & $\begin{array}{l}\text { Computer-assisted } \\
\text { personal interviewing }\end{array}$ & $\sigma^{*}$ & $\sqrt{ }+$ & $\checkmark$ & & $\checkmark$ & $\checkmark$ & $\checkmark$ \\
\hline & $\begin{array}{l}\text { Active Lives: } \\
\text { Children and Young } \\
\text { People Survey }^{22}\end{array}$ & $\begin{array}{l}\text { Sport England } \\
\text { in partnership } \\
\text { with government } \\
\text { departments }\end{array}$ & Ipsos MORI & $\begin{array}{l}\text { School-based, } \\
\text { self-administered } \\
\text { online. Additional } \\
\text { teacher and parent } \\
\text { questionnaires }\end{array}$ & & $\checkmark$ & & & & & \\
\hline \multirow[t]{3}{*}{$\begin{array}{l}\text { Northern } \\
\text { Ireland }\end{array}$} & $\begin{array}{l}\text { Health Survey for } \\
\text { Northern Ireland }\end{array}$ & $\begin{array}{l}\text { Department of } \\
\text { Health }\end{array}$ & $\begin{array}{l}\text { Central Survey } \\
\text { Unit of the } \\
\text { Northern } \\
\text { Ireland } \\
\text { Statistics and } \\
\text { Research } \\
\text { Agency }\end{array}$ & $\begin{array}{l}\text { Computer-assisted } \\
\text { personal interviewing }\end{array}$ & $\checkmark$ & & $\checkmark$ & & $\checkmark$ & $\checkmark$ & \\
\hline & $\begin{array}{l}\text { Young Persons' } \\
\text { Behaviour and } \\
\text { Attitudes Survey }^{23}\end{array}$ & $\begin{array}{l}\text { Department of } \\
\text { Health }\end{array}$ & $\begin{array}{l}\text { Central Survey } \\
\text { Unit of the } \\
\text { Northern } \\
\text { Ireland } \\
\text { Statistics and } \\
\text { Research } \\
\text { Agency }\end{array}$ & $\begin{array}{l}\text { Self-administered } \\
\text { personal interviewing } \\
\text { (now uses tablets) }\end{array}$ & & $\checkmark$ & & & & & $\ddagger$ \\
\hline & $\begin{array}{l}\text { Continuous } \\
\text { Household Survey }{ }^{19}\end{array}$ & $\begin{array}{l}\text { A number of } \\
\text { Government } \\
\text { Departments and } \\
\text { Agencies }\end{array}$ & $\begin{array}{l}\text { Central Survey } \\
\text { Unit of the } \\
\text { Northern } \\
\text { Ireland } \\
\text { Statistics and } \\
\text { Research } \\
\text { Agency }\end{array}$ & $\begin{array}{l}\text { Computer-assisted } \\
\text { personal interviewing }\end{array}$ & & $\checkmark$ & & & & & \\
\hline Scotland & $\begin{array}{l}\text { Scottish Health } \\
\text { Survey }^{18}\end{array}$ & $\begin{array}{l}\text { The Scottish } \\
\text { Government }\end{array}$ & $\begin{array}{l}\text { Scottish Centre } \\
\text { for Social } \\
\text { Research }\end{array}$ & $\begin{array}{l}\text { Computer-assisted } \\
\text { personal interviewing }\end{array}$ & $\checkmark$ & $\checkmark$ & $\checkmark$ & & $\checkmark$ & $\checkmark$ & $\checkmark$ \\
\hline Wales & $\begin{array}{l}\text { National Survey for } \\
\text { Wales }^{20}\end{array}$ & Welsh Government & $\begin{array}{l}\text { Office for } \\
\text { National } \\
\text { Statistics }\end{array}$ & $\begin{array}{l}\text { Computer-assisted } \\
\text { personal interviewing }\end{array}$ & $\checkmark$ & $\checkmark$ & & & & & $\ddagger$ \\
\hline $\begin{array}{l}\text { England, } \\
\text { Scotland, } \\
\text { Wales }\end{array}$ & $\begin{array}{l}\text { Health Behaviour } \\
\text { in School-Aged } \\
\text { Children }^{24-26}\end{array}$ & $\begin{array}{l}\text { Supported by WHO } \\
\text { and other partners }\end{array}$ & $\begin{array}{l}\text { Undertaken by } \\
\text { a consortium } \\
\text { of academics } \\
\text { from different } \\
\text { countries }\end{array}$ & $\begin{array}{l}\text { School-based, } \\
\text { self-administered } \\
\text { questionnaires, } \\
\text { varying methods of } \\
\text { administration }\end{array}$ & & $\checkmark$ & & & & & $\ddagger$ \\
\hline
\end{tabular}

* Official statistic provided by Active Lives Survey not the Health Survey for England.

tAlso reports on recommendation for under $5 \mathrm{~s}$ separately to children 5-15 years old.

$\ddagger$ Some measure of a specific behaviour or domain, most commonly TV/screen time.

MVPA, moderate-to-vigorous physical activity.

cover occupational activity. ${ }^{21}$ The NSW questionnaire is the only one to use a 7-day as opposed to 4-week recall period and does not ask about specific activities. ${ }^{20}$ All surveys distinguish between moderate and vigorous intensity activities, enabling recommendation compliance to be calculated for those who do a combination of PA intensities. In general, MVPA questions are repeated annually (see online supplementary table 1 ). The two exceptions are the HSE and HSNI that include their full questionnaire periodically, but include a variation of the International Physical Activity Questionnaire Short Form (IPAQ-short) in intervening years. ${ }^{16}{ }^{17}$ All surveys ask the questions of those aged $\geq 16$ years, although only the HSE and HSNI report separately on those over 19 years, which is the age range that the recommendation applies to. ${ }^{16} 17$

\section{Children and young people}

As shown in table 3, considerable variation exists in the methods and questionnaires used to measure the percentage of children meeting the MVPA recommendation (60 min daily). The SHeS, HSE and ALS: Children and Young People survey use relatively long and detailed domain-specific questionnaires, ${ }^{16} 1822$ while the YPBAS, ${ }^{23}$ the $\mathrm{CHS}^{19}$ and the HBSC surveys ${ }^{24-26}$ use similar variations of single-item questionnaires asking respondents to indicate on which days they achieved $60 \mathrm{~min}$ of MVPA. The NSW uses an extended version of this single item, asking for a summary duration of MVPA for each day of the previous week. ${ }^{20}$ The age ranges differ between surveys, and no surveys include young people 16-18 years old in their prevalence estimates. 


\begin{tabular}{|c|c|c|c|}
\hline Country & Survey & Current questionnaire & Latest prevalence estimate \\
\hline \multirow[t]{2}{*}{ England } & Active Lives Survey & $\begin{array}{l}\text { 4-week recall period } \\
\text { Frequency of sessions, duration of average session } \\
\text { Walking, cycling, sport and exercise activities, dance, gardening } \\
\text { Asked of all } \geq 16 \text { years }\end{array}$ & $\begin{array}{l}\text { Aged } \geq 16 \text { years: } \\
62 \% \\
\text { M: } 65 \% \mathrm{~W}: 60 \% \\
(2017-2018)^{21}\end{array}$ \\
\hline & Health Survey for England & $\begin{array}{l}\text { 4-week recall period } \\
\text { Frequency of sessions, duration of average session } \\
\text { Walking, heavy housework, gardening/manual, sport and exercises, } \\
\text { six items on occupational activity } \\
\text { Included approximately every } 4 \text { years } \\
\text { Asked of all aged } \geq 16 \text { years, data reported for } \geq 16, \geq 19,19-64 \text {, } \\
\geq 65 \text { years }\end{array}$ & $\begin{array}{l}\text { Aged } \geq 19 \text { years: } \\
62 \% \\
\text { M: } 66 \% \text { W: } 58 \% \\
(2016)^{33}\end{array}$ \\
\hline Northern Ireland & $\begin{array}{l}\text { Health Survey for Northern } \\
\text { Ireland }\end{array}$ & $\begin{array}{l}\text { Same as the Health Survey for England } \\
\text { Asked of all aged } \geq 16 \text { years, reported for } \geq 19 \text { years }\end{array}$ & $\begin{array}{l}\text { Aged } \geq 19 \text { years: } \\
55 \% \\
\text { M: } 61 \% \text { W: } 51 \% \\
(2016-2017)^{66}\end{array}$ \\
\hline Wales & National Survey for Wales & $\begin{array}{l}\text { 7-day recall period } \\
\text { Specific daily durations of walking, moderate, vigorous intensity } \\
\text { activity } \\
\text { Only asked of a subsample in some survey years } \\
\text { Asked of all aged } \geq 16 \text { years }\end{array}$ & $\begin{array}{l}\text { Aged } \geq 16 \text { years: } \\
54 \% \\
\text { M: } 57 \% \text { W: } 51 \% \\
(2016-2017)^{67}\end{array}$ \\
\hline
\end{tabular}

\section{$\mathrm{M}$, men; W, women.}

Parents usually proxy report for children under 10 years. The questionnaires have barely changed in the last decade, but their frequency of inclusion in the survey varies (see online supplementary table 2).
The only survey to report on the MVPA recommendation in the under $5 \mathrm{~s}$ is the HSE. ${ }^{27}$ Parents of children in this age group are asked the same questionnaire as for children 5-15 years old. Compliance with the recommendation is monitored by setting

Table 3 Overview of the UK national surveys that measure compliance with the child MVPA recommendation

\begin{tabular}{|c|c|c|c|}
\hline Country & Survey & Current questionnaire & Latest prevalence estimate \\
\hline \multirow[t]{2}{*}{ England } & Health Survey for England & $\begin{array}{l}\text { 7-day recall period with activities reported on specific days } \\
\text { Domain specific, including activity at school } \\
\text { Asked of all } 2-15 \text { years, proxy report up to age } 12 \\
\text { Children } 2-4 \text { years old analysed separately against the under } 5 \text { s recommendation }\end{array}$ & $\begin{array}{l}\text { Children } 2-4 \text { years old: } \\
\text { 9\% } \\
\text { B: } 10 \% \text { G: } 9 \% \\
\text { Children 5-15 years old: } \\
21 \% \\
\text { B: } 24 \% \text { G: } 18 \% \\
(2015)^{27}\end{array}$ \\
\hline & $\begin{array}{l}\text { Active Lives: Children and Young } \\
\text { People Survey }\end{array}$ & $\begin{array}{l}\text { Adaptive recall period } 7 \text { days } / 4 \text { weeks to suit frequency } \\
\text { Activities in past week reported on specific days } \\
\text { Asked of years } 1-11 \text { (approximately } 5-15 \text { years) } \\
\text { Questionnaire adapted to age of child } \\
\text { Supplementary information from parents and teacher questionnaires }\end{array}$ & $\begin{array}{l}\text { Children } 5-16 \text { years old: } \\
\text { B: } 20 \% \text { G: } 14 \%(2017 / 2018)^{68}\end{array}$ \\
\hline \multirow[t]{2}{*}{ Northern Ireland } & $\begin{array}{l}\text { Young Persons' Behaviour and } \\
\text { Attitudes Survey }\end{array}$ & $\begin{array}{l}\text { Single-item question asking how many days in last } 7 \text { days undertaken } \geq 60 \text { min MVPA } \\
\text { Also questions to give greater detail on specific activity participation over } 7 \text {-day/12- } \\
\text { month time period } \\
\text { - Asked of children } 11-16 \text { years old }\end{array}$ & $\begin{array}{l}\text { Children } 11-16 \text { years old: } \\
\text { 13\% } \\
\text { B: } 17 \% \text { G: } 8 \% \\
(2016)^{69}\end{array}$ \\
\hline & Continuous Household Survey & $\begin{array}{l}\text { Single item on time spent in other sport and exercise activities per day } \\
\text { Unanchored recall period ('on average') } \\
\text { Detailed active travel questions not included in prevalence estimate } \\
\text { Asked of school children aged 4-19 years, parental proxy report for younger children }\end{array}$ & $\begin{array}{l}\text { Primary school: } \\
39 \% \\
\text { Post-primary school: } \\
26 \% \\
(2016 / 2017)^{70}\end{array}$ \\
\hline Scotland & Scottish Health Survey & $\begin{array}{l}\text { 7-day recall period, with activities reported on specific days } \\
\text { Domain specific, including activity at school } \\
\text { Asked of all } 2-15 \text { years, parent proxy report for younger children } \\
\text { Headline figures reported for children } 5-15 \text { years old (and 4-year-olds at school) } \\
\text { No reporting on the under } 5 \mathrm{~s} \text { recommendation }\end{array}$ & $\begin{array}{l}\text { Children } 5-15 \text { years old: } \\
33 \% \\
\text { B: } 36 \% \text { G: } 31 \% \\
(2017)^{71}\end{array}$ \\
\hline Wales & National Survey for Wales & $\begin{array}{l}\text { Duration of any MVPA reported for each day in last } 7 \text { days } \\
\text { Proxy report for all ages (only asked of those aged 3-7) from parent }\end{array}$ & $\begin{array}{l}\text { Children } 3-7 \text { years old: } \\
51 \% \\
\text { B: } 55 \%, \text { G: } 47 \% \\
(2016-2017)^{67}\end{array}$ \\
\hline $\begin{array}{l}\text { England, Scotland, } \\
\text { Wales }\end{array}$ & $\begin{array}{l}\text { Health Behaviour in School-Aged } \\
\text { Children }\end{array}$ & $\begin{array}{l}\text { Single-item question where respondents report the days in last seven when undertaken } \\
\geq 60 \mathrm{~min} \text { MVPA } \\
\text { Children } 11,13,15 \text { years old, school-based survey }\end{array}$ & $\begin{array}{l}15 \%-19 \% \\
\text { B: } 20 \%-22 \% \\
\text { G: } 11 \%-15 \% \\
(2014)^{24-26}\end{array}$ \\
\hline
\end{tabular}


the threshold at 180 min per day rather than 60 . However, the aerobic recommendation for the under $5 \mathrm{~s}$ age group includes 'light' intensity PA, whereas the HSE only asks about MVPA. Thus, information on 'light' intensity PA, which should be included in the prevalence estimate for under $5 \mathrm{~s}$, is not collected.

\section{Measurement of muscle strengthening activity}

The HSE, SHeS and the HSNI can all estimate the percentage of adults and older adults undertaking muscle strengthening activity on at least 2 days per week. ${ }^{16-18}$ This is based on the reported frequencies of sport and exercise activities which are considered to be muscle strengthening such as climbing, rowing and swimming (see Strain $e t a l^{28}$ ). The ALS and the NSW do not measure this recommendation. ${ }^{20} 29$

Reporting on the percentage of the population meeting the muscle strengthening recommendation has been inconsistent. The HSE last reported relevant figures in 2012 (34\% men and $24 \%$ women), ${ }^{30}$ the SHeS in 2015 (30\% men and $25 \%$ women $)^{31}$ and the HSNI in 2013/2014 (25\% men and 14\% women). ${ }^{32}$ The HSE and SHeS have since reported on the percentages of the population meeting both the MVPA and the muscle strengthening recommendations in 2016/2017 (HSE: 31\% men, 23\% women; SHeS: $30 \%$ men, $25 \%$ women). ${ }^{33}$ Given that only $1 \%$ of the population meet the muscle strengthening but not the MVPA recommendation, ${ }^{33} 34$ these figures are reasonable estimates of the percentage of the population meeting the recommended frequency of muscle strengthening exercise.

Children and young people are recommended to undertake vigorous intensity activities, including those that strengthen muscle and bone, at least 3 days a week. These activities are not specifically assessed in any of the UK surveys, meaning national prevalence has not been estimated.
Measurement of balance and co-ordination

The older adult recommendations include balance and co-ordination improving activities on at least 2 days per week for those at risk of falls. The HSE and SHeS estimate the proportion of all adults $\geq 65$ years meeting this recommendation, although the surveys are not designed to identify individuals who are 'at risk of falls ${ }^{16}{ }^{18}$ This is based on reported participation in balance and co-ordination improving activities such as dance, martial arts, tai chi and a wide range of sports. The HSNI could use the same method to derive estimates, but have not yet published these results. ${ }^{1735}$ The ALS and NSW do not measure this recommendation. ${ }^{20} 21$

In the HSE's and SHeS' annual reports, balance and co-ordination improving PA is rarely reported. Strain et al used SHeS data from 2012 to 2014 to estimate that $19 \%$ of older men and $12 \%$ of older women in Scotland met the balance and co-ordination recommendation. ${ }^{28}$ In 2016, the HSE reported the prevalence by MVPA level: $27 \%$ of those $\geq 65$ years meeting the MVPA recommendation also undertook the recommended level of balance and co-ordination activities. Only $11 \%$ of the 'low/some activity' group (30-149 $\mathrm{min} /$ week) met the balance recommendation, while $2 \%$ of the 'inactive' group $(<30 \mathrm{~min} /$ week) did. ${ }^{33}$

\section{Measurement of sedentary behaviour}

Table 4 and online supplementary table 3 present the questions used to report on the SB of adults in the four national surveys over the last decade. Empirical work over the past two decades has reported SB to be associated with a host of negative cardiometabolic health outcomes and premature mortality. ${ }^{36} 37$ In line with this evidence, advice to reduce SB has been included

Table 4 Questions on sedentary behaviour for adults and children in national surveys since 2008

\begin{tabular}{|c|c|c|c|c|c|c|c|c|c|c|c|c|c|}
\hline \multirow[b]{2}{*}{ Country } & \multirow[b]{2}{*}{ Survey } & \multirow[b]{2}{*}{ Population } & \multicolumn{10}{|l|}{ Year } & \multirow{2}{*}{$\begin{array}{l}\text { Most recent prevalence } \\
\text { statistics }\end{array}$} \\
\hline & & & 2017 & 2016 & 2015 & 2014 & 2013 & 2012 & 2011 & 2010 & 2009 & 2008 & \\
\hline \multirow[t]{2}{*}{ England } & \multirow{2}{*}{$\begin{array}{l}\text { Health Survey for } \\
\text { England }\end{array}$} & Adults & $?$ & B & $\mathrm{E}$ & $\mathrm{E}$ & $\mathrm{E}$ & B & $x$ & $x$ & $x$ & $\mathrm{~B}+$ & Mean: 4.7 hours/weekday ${ }^{33} \ddagger$ \\
\hline & & Children & $?$ & $x$ & D & $x$ & $x$ & D & $x$ & $x$ & $x$ & $\mathrm{Dt}$ & Mean: 3.0 hours/weekday ${ }^{27}$ \\
\hline \multirow[t]{2}{*}{$\begin{array}{l}\text { Northern } \\
\text { Ireland }\end{array}$} & $\begin{array}{l}\text { Health Survey for } \\
\text { Northern Ireland }\end{array}$ & Adults & B & E & $\mathrm{x}$ & B & $?$ & $\mathrm{x}$ & $\mathrm{x}$ & & & & $\begin{array}{l}44 \% \text { adults report } \geq 4 \text { hours/ } \\
\text { weekday } 35\end{array}$ \\
\hline & $\begin{array}{l}\text { Young Persons' } \\
\text { Behaviour and } \\
\text { Attitudes Survey }\end{array}$ & Children & & $S$ & & & $S$ & & & $S$ & & & Not reported \\
\hline \multirow[t]{4}{*}{ Scotland } & \multirow{2}{*}{$\begin{array}{l}\text { Scottish Health } \\
\text { Survey }\end{array}$} & Adults & A & $A$ & A & A & A & A & $x$ & G & $x$ & G & Mean: 5.2 hours/weekday ${ }^{34} \ddagger$ \\
\hline & & Children & C & C & C & c & C & C & $x$ & $x$ & $x$ & G & Mean: 3.4 hours/weekday ${ }^{34}$ \\
\hline & \multirow{2}{*}{$\begin{array}{l}\text { Welsh Health } \\
\text { Survey* }^{*}\end{array}$} & Adults & & & $\mathrm{F}$ & $\mathrm{x}$ & $\mathrm{x}$ & $\mathrm{x}$ & $\mathrm{x}$ & $\mathrm{x}$ & $\mathrm{x}$ & $\mathrm{x}$ & None published \\
\hline & & Children & & & $x$ & $x$ & $x$ & $x$ & $x$ & $x$ & $x$ & $x$ & $\mathrm{~N} / \mathrm{A}$ \\
\hline \multirow[t]{2}{*}{ Wales } & \multirow{2}{*}{$\begin{array}{l}\text { National Survey for } \\
\text { Wales }\end{array}$} & Adults & $\mathrm{x}$ & & & & & & & & & & $N / A$ \\
\hline & & Children & s & & & & & & & & & & $\begin{array}{l}81 \% \text { report } \geq 2 \text { hours screen } \\
\text { time/weekday }{ }^{67}\end{array}$ \\
\hline $\begin{array}{l}\text { England, } \\
\text { Scotland, } \\
\text { Wales }\end{array}$ & $\begin{array}{l}\text { Health Behaviour } \\
\text { in School-Aged } \\
\text { Children }\end{array}$ & Children & & & & $S$ & & & & $S$ & & & $\begin{array}{l}61 \%-68 \% \text { report watching TV/ } \\
\text { DVDs for } \geq 2 \text { hours/weekday }{ }^{24-26}\end{array}$ \\
\hline
\end{tabular}

Surveys crossing successive years (eg, 2015-2016) are reported under the second year. Blank cells indicate survey not conducted in that year or years when the National Survey for Wales did not include questions on health. Questionnaires for adults apply to those aged 16+, questionnaires for children apply to those aged 2 to 15 .

Key (see online supplementary table 3 for full description of questions): A: sum of behaviours (work; TV; other (not TV not work)), long recall period; B: sum of behaviours (work (sit and stand); TV; other (not TV not work)), long recall period; C: sum of behaviours (TV; other (not TV, not school)), unanchored recall period; D: sum of behaviours (TV; other (not TV, not school)), previous week recall period; E and F: single-item direct measure, previous week recall period; G: single-item proxy measure (TV), long recall period (previous 4 weeks); S: asked questions about screen time, which cannot be directly ascribed to sitting; $X$ : no questions asked about SB; ? indicates documentation not yet published/not clear from documentation; N/A, not applicable.

*Included in table as it was one of a number of surveys to be combined into the National Survey for Wales. tAdditionally, piloted device-based measurement, using hip-worn ActiGraph (not a postural measure of sitting).

¥Sitting time at work/school not included in these estimates. 
in the CMO PA guidelines since 2011. SB questions were included in surveillance infrequently across all age groups, but were less common in children's questionnaires than adults'. For example, the NSW and its predecessor, the Welsh Health Survey, included SB questions only once for adults and never for children. The SHeS has the most consistent measurement of SB for both adults and children, asking the same questions annually since 2012 .

The type of SB questionnaires has been consistent, falling into two broad groups. One group of single-item questions about total sitting time (reported in hours and minutes), with a previous week recall period of weekdays only (a version of the IPAQshort), ${ }^{38}$ are only asked of adults. The other group, asked of both adults and children, includes composite measures of behaviours: work; TV viewing; other, described as any non-work (adults) or school (children) otherwise not reported. Although adults were sometimes asked about work in these composite questions, children were never asked an equivalent question about sitting time at school. For adults, the recall period of the questions was the last 4 weeks. For children, it was either unanchored (ie, a typical week) or for the previous week. Two of these SB behaviours (TV and other) were asked separately for week and weekend days, whereas questions about work SB were asked about the work day. As with the MVPA questions, parents usually proxy report for children under 10 years.

Reporting of SB results in the annual reports from the national surveys is even more sporadic than its measurement. For example, the SHeS has included SB questions every year since 2012, but only reported on them in the main survey report in 2012 and 2015. Additionally, the HSE and SHeS have only reported on leisure time SB, and did not include time spent sitting at work. As the 2011 guidelines do not provide a recommended threshold for sitting, surveys can only report population estimates of time spent sitting. Other surveys use different metrics, such as the proportion that report sitting or watching TV for more than a given number of hours per day, for example, HSNI (adults), NSW (children) and HBSC (children).

\section{DISCUSSION}

\section{Summary of current UK surveillance}

Surveillance of PA and SB in the UK is complex and fragmented, undertaken separately in each of the four home nations, and across multiple surveys in each country that cover different age groups. Although most of the PA recommendations are covered by at least one of the surveys, the distribution of coverage is variable. Surveys rarely assess children under 5 for compliance to their age group-specific recommendations. Despite slight differences in the recommendations for adults and older adults, estimates for these two groups are not reported separately. Some aspects of the adult and older adult recommendations are not currently assessed in some home nations; for example, Wales does not assess SB, muscle strengthening or balance. The child muscle and bone strengthening recommendation is not measured by any nation.

As we move forward with the forthcoming 2019 recommendations, it is timely to consider whether the UK PA and SB surveillance system can be improved. It is important to consider potential risks and benefits for change, and alternative approaches to the existing surveys. The final wording of the 2019 recommendations will undoubtedly influence surveillance decisions.

\section{Validity of survey questions}

Validation of the questions used in UK surveillance is limited. The current HSE adult MVPA questions, also used in the HSNI, performed comparably with other self-report instruments when compared with uni-axial waist-worn accelerometers (correlation coefficients 0.32-0.42). ${ }^{39} 40$ The questionnaire also produced lower prevalence estimates than the IPAQ-short by $\sim 10 \%-20 \%$, although the magnitude of this difference across demographic categories was similar. ${ }^{41}$ The mean daily minutes derived from a previous, but comparable, version of the SHeS child MVPA questionnaire were, on average, 122 min per day higher than those derived from uni-axial waist-worn accelerometers. ${ }^{42}$

Regarding SB, a recent large validation study of older adults $(n=700)$ used the TASST framework to assess the effect of two dimensions (type of assessment $n=6$, recall period $n=3$ ) in a systematic manner (in a $6 \times 3$ grid, testing 18 combinations) against a device-derived postural measure of SB. ${ }^{43}$ This methodology allowed for generalisable statements to be made as to the optimal method of assessing self-reported SB. Measurement was poor for all combinations, and the authors recommended that a correction factor should be added to the self-reported SB to adjust the population mean value. In general, questions asking about SB as a sum of time spent in individual behaviours, as commonly used in national surveys, were the type of assessment that performed worst. A single question, a visual analogue scale of the proportion of the waking day spent sitting (eg, online supplementary figure 1), fared best in terms of precision and feasibility (missing data or survey non-response). ${ }^{43}$

\section{Do differences in questions affect prevalence estimates?}

The child MVPA questions have differed in terms of assessing whether a child has undertaken $\geq 60 \mathrm{~min}$ of MVPA on every day in the last week (HSE, HSNI, SHeS from 2017) or achieved an average of $60 \mathrm{~min}$ across the week (SHeS until 2016). Such inconsistent interpretations lead to an approximate difference of $30 \%$ in prevalence estimates. ${ }^{44}$

For adult MVPA, occupational behaviour is often assessed separately from other $\mathrm{PA}$ and $\mathrm{SB}$, making it difficult to calculate total PA and SB volume estimates. The HSE and HSNI use multiple questions to derive total minutes of adult MVPA at work per week, whereas the SHeS uses a single question. This makes a substantial difference to the estimated total weekly minutes, ${ }^{45} 46$ but unpublished work suggests it may not affect estimates of the percentage meeting the recommendations. ${ }^{47}$ Regarding SB, the HSE and HSNI ask a single question about time spent both sitting and standing at work, meaning occupational SB cannot be assessed separately. Although occupational SB is questioned separately in the SHeS, it is not reported as part of total sitting time. Many working age adults spend a considerable part of their working day sitting. ${ }^{48}$ Reporting selectively on leisure time $S B$ can may be misleading and, compared with total sitting (work and leisure), can lead to distorted estimates of SB distribution in the population. ${ }^{349}$ Comprehensive assessment of SB across the whole day/all domains should also apply to children in future surveillance.

\section{Harmonisation of questionnaires}

The large variation in questionnaires, administration methods and sample populations in UK surveillance hinders cross-national comparisons. This point was emphasised in the recent WHO Global Action Plan for $\mathrm{PA}^{50}$ and is all the more important given the part-devolved, part-reserved nature of governance in the UK. The four CMOs overcame this organisational structure 
to jointly present the 2011 PA recommendations and will do again for the forthcoming 2019 update. We challenge professionals and academics involved in health surveillance to do the same as comparisons between nations are undermined if differences in the survey methods cause greater differences in prevalence than any likely true difference in population PA levels. An important counterpoint to harmonising measurement across countries/surveys is that trend data are also critical to inform and evaluate policies, meaning there has to be a strong rationale to depart from the methods used in previous surveys. As the 2019 recommendations could require trend-disrupting changes such as the removal of the 10 min minimum bout duration, ${ }^{51}$ the discussion about methods harmonisation is extremely timely.

The adult MVPA questions of the HSE and HSNI questionnaires are directly comparable, and they have only minor differences to the SHeS. These surveys are also those with the longest running trend data (see online supplementary table 1 for trends since 2008). However, they are much longer than the NSW questionnaire, and space is at a premium across all surveys. A possible solution would be to include the HSE/ HSNI questionnaire once every 4 years in SHeS and HSNI, with the existing questionnaires in the intervening years. Yet, this solution does not suit the SHeS because of the need to pool consecutive years of data to generate local authority level estimates.

Another alternative is the IPAQ-short, as similar questions have been used in all countries but Scotland (see online supplementary table 1). However, this would not provide domain-specific information. The Global Physical Activity Questionnaire (GPAQ) is another alternative, ${ }^{52}$ but would result in the loss of the muscle strengthening and balance prevalence estimates which rely on the detailed sport and exercise questions. ${ }^{53} \mathrm{An}$ advantage of these two questionnaires is that they are the most commonly used globally, ${ }^{8}$ enabling wider comparisons.

For child MVPA, variations of the HBSC questionnaire have been used in all countries except Scotland (see online supplementary table 2), but again this does not provide domain-specific information. The recent change in response categories to the $\mathrm{SHeS}$ questionnaire has meant that comparable estimates with the HSE may be derived, but the questionnaires are much longer than those currently used in other surveys, meaning that their adoption is unlikely.

Changing the muscle strength and balance questions may be something policy-makers are willing to consider, given that trend data on these recommendations have not been widely integrated into policy-making. However, the UK is leading international surveillance in this area: only two out of 114 other countries' main national surveys specifically assess muscle strengthening, and none assess balance. ${ }^{53}$ It would therefore be regressive to lose the ability to monitor prevalence against these recommendations.

Moving to a single SB question assessing the whole day using a visual analogue scale is worth considering (see online supplementary figure 1), as the inconsistent nature of SB monitoring and reporting across all surveys means that policy-influencing trend data have not yet been established. A single question would reduce pressure on inclusion constraints for surveys, and other policy-directed questions (eg, context of SB) could be asked additionally in each survey as required.

In summary, there are costs and benefits to every potential solution. Survey funders, managers and researchers need to be involved in any decisions that are made to ensure that the views of all stakeholders are considered.

\section{Alternatives to questionnaire measurement}

The recent WHO Global Action Plan on PA advocated the development and testing of new technologies for PA surveillance. ${ }^{50}$ In the UK, hip-worn accelerometers were trialled once for a subsample of the $2008 \mathrm{HSE}$, but were not adopted into national surveillance. ${ }^{39}$ Internationally, several national surveys (eg, $\mathrm{USA}^{54}$ ) incorporate device-based measurement of PA. In addition, large-scale accelerometry data have been collected in the UK among both adults (UK Biobank ${ }^{55}$ and 1970 British Birth Cohort $^{56}$ ) and children (the Growing Up in Scotland Study ${ }^{57}$ and Millennium Cohort Study ${ }^{58}$ ).

Estimates for total time spent in MVPA and SB derived from accelerometers are more accurate than those from questionnaires. ${ }^{43} 59$ However, widespread adoption in surveillance requires consideration of practical concerns, including investment in processes, compliance and understanding how adoption of newer technology in different survey years will influence trend data. ${ }^{54560}$ No device can measure all aspects of the PA recommendations. Preferred devices and wear locations are different for measuring MVPA and SB. ${ }^{5461}$ Furthermore, no device can currently quantify muscle strengthening and balance activity.

Grip strength is an objective measure of muscle strength that has previously been used in the $2005 \mathrm{HSE}^{62}$ As a quick and straightforward measure that correlates well with mortality and cardiovascular disease risk, ${ }^{6364}$ it may be suitable for re-inclusion in the future. However, it is a measure of fitness rather than engagement in the behaviours themselves.

In general, these measures do not assess context, ${ }^{15}$ which may be of policy interest. Conceptual differences in what devicebased and self-report methods assess mean that recommendations derived from self-reported instruments (ie, $150 \mathrm{~min}$ MVPA) may not be appropriate for device-based measurement. ${ }^{54}$

The growth and popularity of wearable technologies to track activity and health may provide a feasible mechanism for assessing $\mathrm{PA}$ and $\mathrm{SB}$, potentially through consented access to data stored in respondents' own devices. Yet, what information such monitors actually capture and output varies and there are potential biases due to unequal distribution in ownership of such devices across the population (eg, greater ownership among younger and more active individuals). ${ }^{65}$

\section{Strengths and limitations}

This is the first comprehensive review to describe PA and SB surveillance in the UK and will help initiate a meaningful discussion on future surveillance possibilities. This review will be of use to those interested in PA and SB surveillance within the UK and beyond. These issues are increasingly important to understand as the Go-PA! country cards and Active Healthy Kids Report Cards initiatives grow.

There are a number of limitations to the present work. The non-systematic nature of the literature search means that it is possible that some surveys have been overlooked. However, the approach used was the only realistic method to employ given the 'grey' nature of the literature. We were also limited by the availability of documentation: not all surveys had comprehensive methodological documentation, particularly for previous iterations. Also, the current questions may be subject to change in the near future and/or do not represent usual circumstances. Where this was a concern, we tried to contact the survey co-ordinators/administrators, although this was not always possible. Our framework of reviewing surveillance methods against the existing age-grouped recommendations meant that we were unable to explore whether there are specific surveillance issues 
relating to other population groups such as those with disabilities and/or chronic conditions. Finally, our work relates mostly to the 2011 UK PA recommendations. New recommendations will be published in 2019 that may raise new issues and resolve some of those highlighted. However, this work provides the necessary background to inform those decisions, as it is highly probable that the same surveys will be central to PA and SB surveillance across the UK. This comprehensive summary of the numerous inter-related issues should enable a UK-wide strategy to be developed.

\section{Recommendations}

Our results have highlighted the 'patchwork quilt' nature of PA and SB surveillance in the UK. With the forthcoming 2019 update in mind, ${ }^{10}$ we recommend a calculated move towards harmonisation of questionnaires and, where possible, survey methods. We have presented a number of self-report options that should be considered:

- Harmonising to one of the existing questionnaires across all surveys that optimises the maintenance of current trend data;

- Introducing an internationally used questionnaire such as the IPAQ-short or GPAQ for adult MVPA while retaining a method of assessing muscle strengthening and balance activities; and

- Introducing a single-item question for SB using a visual analogue scale response.

We have also presented some of the advantages and disadvantages of these suggestions. It will be important that funders, survey managers and researchers take any decisions jointly. Given the competing pressures on national surveys, the eventual outcome may not be the optimal method that one would recommend for a large-scale research study.

We also recommend that the introduction of device-based measures is considered and that the practical and technical barriers specific to their introduction into UK surveillance are established. We suggest that the use of wearable trackers is considered at an early stage, putting the UK at the forefront of developments in PA and SB surveillance.

\section{What are the new findings?}

- Monitoring the percentages of people who meet the physical activity recommendations in the UK is complex, and is undertaken separately in each of the home nations, using multiple surveys that cover adults and children separately.

- There is no part of the recommendations for which comparable estimates can be calculated across all four home nations.

- We recommend that the costs and benefits of harmonising the existing questionnaires are considered, along with the potential introduction of device-based measures.

Correction notice This article has been corrected since it published Online First. The subtitle title 'Measurement of sedentary behaviour' has been corrected.

Acknowledgements We would like to thank all those involved in the national surveys: the participants, the funders and the survey contractors. We would also like to thank the other members of the Communication and Surveillance Expert Working Group of the 2018 UK Physical Activity Guidelines review who commented on the draft report.

Contributors NM chaired the Expert Working Group for Communication and Surveillance which TS, PD, KM and MS were part of. All authors defined the scope of the work. TS, PD, KM and MS undertook the review and drafted the manuscript. All authors commented on and edited the final manuscript.
Funding The Chief Medical Officers of the four home nations commissioned the Expert Working Groups for the 2019 PA guidelines review and update. TS is supported by the Medical Research Council (grant no. MC_UU_12015/3).

Competing interests None declared.

\section{Patient consent for publication Not required.}

Provenance and peer review Not commissioned; externally peer reviewed.

Open access This is an open access article distributed in accordance with the Creative Commons Attribution 4.0 Unported (CC BY 4.0) license, which permits others to copy, redistribute, remix, transform and build upon this work for any purpose, provided the original work is properly cited, a link to the licence is given, and indication of whether changes were made. See: https://creativecommons.org/ licenses/by/4.0/.

\section{REFERENCES}

1 Physical Activity Guidelines Advisory Committee. 2018 physical activity guidelines Advisory Committee scientific report. Washington DC: US: Department of Health and Human Services, 2018.

2. Warburton DER, Bredin SSD. Health benefits of physical activity: a systematic review of current systematic reviews. Curr Opin Cardiol 2017;32:541-56.

3. Milton K, Bauman A. A critical analysis of the cycles of physical activity policy in England. Int J Behav Nutr Phys Act 2015;12.

4 Department of Health. Start active, stay active: a report on physical activity from the four home countries' chief medical officers. London, UK: Department of Health, 2011.

5 The Sedentary Behaviour and Obesity Expert Working Group. Sedentary behaviour and obesity: review of the current scientific evidence. London, UK: Department of Health, 2010.

6 Strain T, Milton K, Dall P, et al. Assessing population levels of physical activity and sedentary behaviour in the UK - what we do currently and recommendations for future approaches, 2018. Available: http://www.bristol.ac.uk/media-library/sites/sps/ documents/cmo/uk-pa-guidelines-surveillance-report.pdf Archived at: http://www. webcitation.org/77hlkBwlv

7 Hallal PC, Andersen LB, Bull FC, et al. Global physical activity levels: surveillance progress, pitfalls, and prospects. The Lancet 2012;380:247-57.

8 Guthold R, Stevens GA, Riley LM, et al. Worldwide trends in insufficient physical activity from 2001 to 2016: a pooled analysis of 358 population-based surveys with 1.9 million participants. Lancet Glob Health 2018;6:e1077-86.

9 Ramirez Varela A, Salvo D, Pratt M, et al. Worldwide use of the first set of physical activity Country Cards: The Global Observatory for Physical Activity - GoPA! Int J Behav Nutr Phys Act 2018;15.

10 University of Bristol. UK physical activity guidelines review, 2018

11. Harrington DM, Murphy M, Carlin A, et al. Results from Ireland North and South's 2016 Report Card on Physical Activity for Children and Youth. J Phys Act Health 2016;13(11 Suppl 2):S183-S188.

12 Reilly JJ, Johnstone A, McNeill G, et al. Results from Scotland's 2016 report card on physical activity for children and youth. J Phys Act Health 2016;13(11 Suppl 2):S251-S255.

13 Tyler R, Mannello M, Mattingley R, et al. Results from Wales' 2016 report card on physical activity for children and youth: is Wales turning the tide on children's inactivity? J Phys Act Health 2016;13(11 Suppl 2):S330-S336.

14 Wilkie H, Standage M, Sherar L, et al. Results from England's 2016 report card on physical activity for children and youth. J Phys Act Health 2016;13(11 Suppl 2):S143-S149.

15 Dall PM, Coulter EH, Fitzsimons CF, et al. Taxonomy of self-reported sedentary behaviour tools (TASST) framework for development, comparison and evaluation of self-report tools: content analysis and systematic review. BMJ Open 2017;7:e013844-e.

16 UK Data Service. Health survey for England, 2018. Available: http://www.webcitation. org/72e444sR1

17 Department of Health. Health survey Northern Ireland questionnaires, 2016. Available: https://www.health-ni.gov.uk/publications/health-survey-northern-irelandquestionnaires Archived at: http://www.webcitation.org/7315vtYHR

18 Scottish Government. Scottish health survey: reports and publications, 2018. Available: https://www.gov.scot/Topics/Statistics/Browse/Health/scottish-healthsurvey/Publications Archived at: http://www.webcitation.org/72e56q8aS

19 Northern Ireland Statistics and Research Agency. Continuous Household Survey Belfast, UK: Northern Ireland statistics and research agency, 2018. Available: https:// www.nisra.gov.uk/continuous-household-survey Archived at: http://www.webcitation. org/72NkvklYc

20 Welsh Government. National survey for Wales design and methodology, 2018. Available: http://gov.wales/statistics-and-research/national-survey/designmethodology/?lang=en Archived at: http://www.webcitation.org/72NnN7RpJ

21 Sport England. Active lives adult survey: may 17/18 report. London, UK: sport England, 2018. Available: https://www.sportengland.org/media/13557/activelives-adult-may-17-18-report.pdf Archived at: http://www.webcitation.org/ $735 \mathrm{M} 5 \mathrm{R} 0 \mathrm{Na}$ 
22 Sport England. The active lives: children and young people Survey—questionnaire content. London, UK: sport England, 2018. Available: https://www.sportengland.org/ media/13277/active-lives-children-and-young-people-survey-questionnaire-overview. pdf Archived at: http://www.webcitation.org/7315mwYvd

23 Northern Ireland Statistics and Research Agency. Young persons' behaviour and attitudes survey, 2017. Available: https://www.nisra.gov.uk/young-persons-behaviourattitudes-survey Archived at: http://www.webcitation.org/72NmtyG34

24 Currie C, Van der Sluijs W, Whitehead R, et al. Health behaviour in school-aged children 2014 survey in Scotland national report. University of St Andrews, UK: Child and Adolescent Health Research Unit (CAHRU), 2015.

25 Brooks F, Magnusson J, Klemera E, et al. Health behaviour in school-aged children England national report 2014. Hatfield, UK: University of Hertfordshire, 2015.

26 Welsh Government. 2013/14 health behaviour in school-aged children Wales: key findings. Cardiff, UK: knowledge and analytical services, Welsh government, 2015. Available: http://gov.wales/docs/caecd/research/2015/151022-health-behaviourschool-children-2013-14-key-findings-en.pdf Archived at: http://www.webcitation. org/72NnXNA49

27 NHS Digital. Health survey for England 2015: children's physical activity tables. Leeds, UK: NHS digital, 2016. Available: http://webarchive.nationalarchives.gov.uk/ 20180307193646/http://digital.nhs.uk/media/30017/Health-Survey-for-England2015-Children-s-physical-activity-tables/Any/HSE2015-Child-phy-act-tab Archived at: http://www.webcitation.org/72e4/4ej9

28 Strain T, Fitzsimons C, Kelly P, et al. The forgotten guidelines: cross-sectional analysis of participation in muscle strengthening and balance $\&$ co-ordination activities by adults and older adults in Scotland. BMC Public Health 2016;16.

29 Sport England. Method behind active lives, 2017. Available: https://www. sportengland.org/research/active-lives-survey/method-behind-active-lives/

30 Scholes S, Mindell J. Health survey for England 2012 chapter 2: physical activity in adults. Leeds, UK: Health and Social Care Information Centre, 2013.

31 Hovald P. Scottish health survey 2015 chapter 7: physical activity. Edinburgh, UK: Scottish Government, 2016

32 Walker H, Scarlett M, Williams B. Health survey Northern Ireland: first results 13/14. Belfast, UK: Public Health Information \& Research Branch, Information Analysis Directorate, 2014.

33 NHS Digital. Health survey for England 2016 adult physical activity—tables. Leeds, UK: NHS digital, 2017. Available: https://files.digital.nhs.uk/publication/m/s/hse16adult-phy-act.xlsx Archived at: http://www.webcitation.org/72NkhG3Uj

34 Scottish Government. Scottish health survey 2017 supplementary tables (parts 6 and 7), 2018. Available: https://www.gov.scot/Topics/Statistics/Browse/Health/scottishhealth-survey/Publications/Supplementary2017 Archived at: http://www.webcitation. org/730nE2coY

35 Department of Health. Health survey Northern Ireland trend tables. Belfast, UK: Department of Health, 2017

36. Biswas A, Oh Pl, Faulkner GE, et al. Sedentary time and its association with risk for disease incidence, mortality, and hospitalization in adults: a systematic review and meta-analysis. Ann Intern Med 2015;162:123-32.

37 Patterson R, McNamara E, Tainio M, et al. Sedentary behaviour and risk of all-cause, cardiovascular and cancer mortality, and incident type 2 diabetes: a systematic review and dose response meta-analysis. Eur J Epidemiol 2018;33:811-29.

38 The IPAQ group. International physical activity questionnaire, 2016. Available: https:// sites.google.com/site/theipaq/Archived at: http://www.webcitation.org/72NmblP9|

39 Scholes S, Coombs N, Pedisic Z, et al. Age- and sex-specific criterion validity of the health survey for England physical activity and sedentary behavior as compared with Accelerometry. Am J Epidemiol 2014;179:1493-502.

40 Helmerhorst HJF, Brage S, Warren J, et al. A systematic review of reliability and objective criterion-related validity of physical activity questionnaires. Int $J$ Behav Nutr Phys Act 2012;9.

41 Scholes S, Bridges S, Ng Fat L, et al. Comparison of the physical activity and sedentary behaviour and the short-form international physical activity questionnaire: an analysis of health survey for England data. Plos One 2016;11:e151647-e.

42 Basterfield L, Adamson AJ, Parkinson KN, et al. Surveillance of physical activity in the UK is flawed: validation of the health survey for England physical activity questionnaire. Arch Dis Child 2008:93:1054-8.

43 Chastin SFM, Dontje ML, Skelton DA, et al. Systematic comparative validation of selfreport measures of sedentary time against an objective measure of postural sitting (activPAL). Int J Behav Nutr Phys Act 2018;15.

44. Williamson C, Kelly P, Strain T. Different analysis methods of Scottish and English child physical activity data explain the majority of the difference between the national prevalence estimates. BMC Public Health 2019;19.

45 Strain T, Fitzsimons $C$, Foster $C$, et al. Age-related comparisons by sex in the domains of aerobic physical activity for adults in Scotland. Prev Med Rep 2016;3:90-7.
46 Roberts D, Townsend N, Foster C. Use of new guidance to profile 'equivalent minutes' of aerobic physical activity for adults in England reveals gender, geographical, and socio-economic inequalities in meeting public health guidance: cross-sectional study. Prev Med Rep 2016;4:50-60.

47 Open Science Framework. Where do people get their activity? Domain-specific physical activity (country comparison): open science framework, 2016. Available: https://osf.io/xkwrq/

48 Ryan CG, Dall PM, Granat MH, et al. Sitting patterns at work: objective measurement of adherence to current recommendations. Ergonomics 2011;54:531-8.

49 Strain T, Kelly P, Mutrie N, et al. Differences by age and sex in the sedentary time of adults in Scotland. J Sports Sci 2018;36:732-41.

50 World Health Organization. Global action plan on physical activity 2018-2030: more active people for a healthier world. Geneva, Switzerland: World Health Organization, 2018.

51 Piercy KL, Troiano RP, Ballard RM, et al. The physical activity guidelines for Americans. JAMA 2018:320:2020-8.

52 Bull FC, Maslin TS, Armstrong T. Global physical activity questionnaire (GPAQ): nine country reliability and validity study. J Phys Act Health 2009;6:790-804.

53 Milton K, Varela AR, Strain T, et al. A review of global surveillance on the muscle strengthening and balance elements of physical activity recommendations. JFSF 2018;03:114-24

54 Troiano RP, McClain JJ, Brychta RJ, et al. Evolution of accelerometer methods for physical activity research. Br J Sports Med 2014;48:1019-23.

55 Doherty A, Jackson D, Hammerla N, et al. Large scale population assessment of physical activity using wrist worn Accelerometers: the UK Biobank study. Plos One 2017;12.

56 Dall PM, Skelton DA, Dontje ML, et al. Characteristics of a protocol to collect objective physical behavior data in a large study: seniors USP (understanding sedentary patterns). J Meas Phys Behav 2018;1:26-31.

57 McCrorie P, Mitchell R, Ellaway A. Comparison of two methods to assess physical activity prevalence in children: an observational study using a nationally representative sample of Scottish children aged 10-11 years. BMJ Open 2018;8.

58 Griffiths LJ, Cortina-Borja M, Sera F, et al. How active are our children? Findings from the millennium cohort study. BMJ Open 2013;3.

59 Steene-Johannessen J, Anderssen SA, van der Ploeg HP, et al. Are self-report measures able to define individuals as physically active or inactive? Med Sci Sports Exerc 2016:48:235-44

60 Matthews CE, Hagströmer M, Pober DM, et al. Best practices for using physical activity monitors in population-based research. Med Sci Sports Exerc 2012;44(1 Suppl 1):S68-S76.

61 Kozey-Keadle S, Libertine A, Lyden K, et al. Validation of wearable monitors for assessing sedentary behavior. Med Sci Sports Exerc 2011;43:1561-7.

62 Craig R, Mindell J. Health survey for England 2005 volume 5 methodology and documentation. Leeds, UK: The Information Centre, 2005.

63. Celis-Morales CA, Welsh P, Lyall DM, et al. Associations of grip strength with cardiovascular, respiratory, and cancer outcomes and all cause mortality: prospective cohort study of half a million UK Biobank participants. BMJ 2018;361.

64. Kim Y, Wijndaele K, Lee D-C, et al. Independent and joint associations of grip strength and adiposity with all-cause and cardiovascular disease mortality in 403,199 adults: the UK Biobank study. Am J Clin Nutr 2017;106:773-82.

65. Strain T, Wijndaele K, Brage S. Physical activity surveillance through smartphone apps and wearable trackers: examining the UK potential for nationally representative sampling. JMIR Mhealth Uhealth. In Press 2019;7.

66 Corrigan D, Scarlett M. Health Survey (Ni): first results 2016/17. Belfast, UK: department of health, 2017. Available: https://www.health-ni.gov.uk/topics/dohstatistics-and-research/health-survey-northern-ireland Archived at: http://www. webcitation.org/72Nlj7szN

67 Welsh Government. National survey for Wales: results viewer, 2018. Available: https:// gov.wales/docs/caecd/research/2018/national-survey-results-viewer-en.xlsb Archived at: http://www.webcitation.org/72NnGFMr7

68 Sport England. Active lives children and young people survey. Academic year 2017/18. London, UK: Sport England, 2018.

69 Foster C, Scarlett M, Stewart B. Young Persons' behaviour and attitude survey 2016 health modules. Belfast, UK: Department of Health, 2017.

70 Department for Infrastructure. Method of travel to/from school by pupils in Northern Ireland, 2016/17. Belfast, UK: Analysis, Statistics and Research Branch, Department for Infrastructure, 2017.

71 Dean L. Scottish health survey 2017 chapter 7: physical activity. Edinburgh, UK: Scottish Government, 2018. 